\title{
A man's bones with 16th-century weapons and coins in a glacier near Zermatt, Switzerland
}

\author{
PeTER LeHNER \& ANNEMARIE JULEN*
}

Late in the 16th century, a man fell into the glacier crossing a high Alpine pass between Switzerland and Italy. The ice has released him these last years.

\section{The locality}

The discovery site is located on the eastern rim of the upper Theodulglacier, $2.5 \mathrm{~km}$ from the Theodulpass (FIGURES 1 \& 2), which connects the valley of Zermatt in Switzerland with the Val Tournanche in Italy, on the southern slope

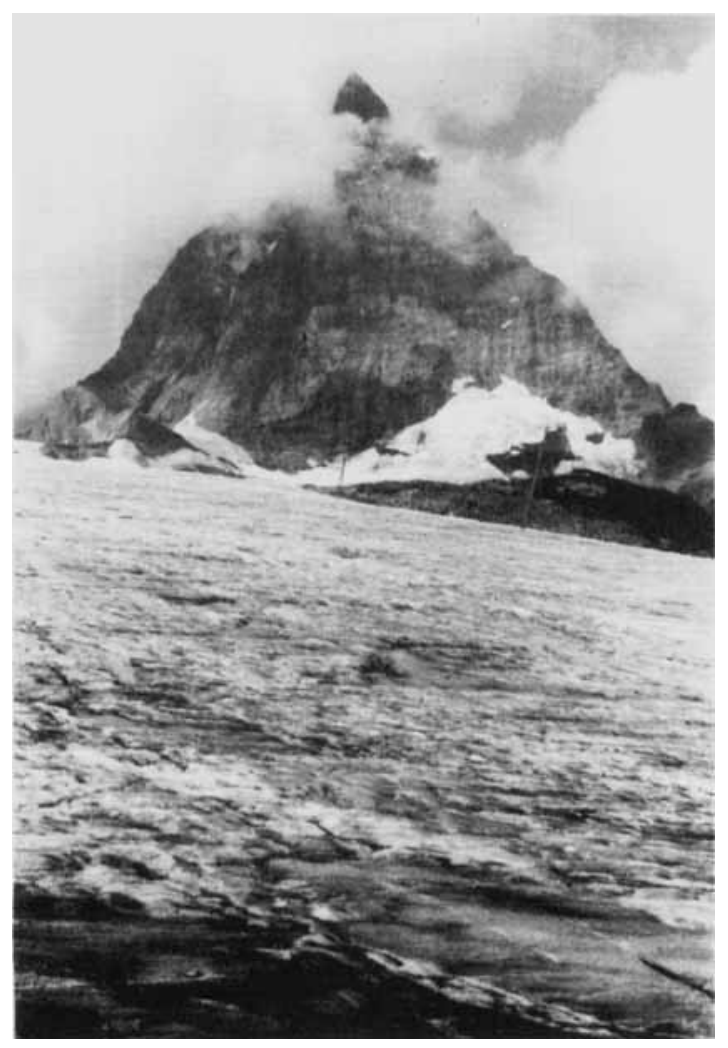

FIGURE 1. The discovery site in 1986 on the eastern rim of the Theodulglacier at an altitude of $3000 \mathrm{~m}$. In the background the Matterhorn. of the Alps. The pass, nowadays only crossed by skiers and mountaineers, was important in medieval times, and to a lesser degree into the last century, for the transport across the border of, mainly, Italian wine and Swiss cattle and sheep.

The crossing, at an altitude of $3300 \mathrm{~m}$, is snow-covered throughout the year. On the discovery site, some $300 \mathrm{~m}$ lower down, the winter snow begins to melt in the late summer; by mid October the glacier is covered with snow again. The intense radiation of the sun at this altitude during approximately two months is sufficient to melt an ice layer of 2-3 m per year. In the past five years the ice rim has retreated

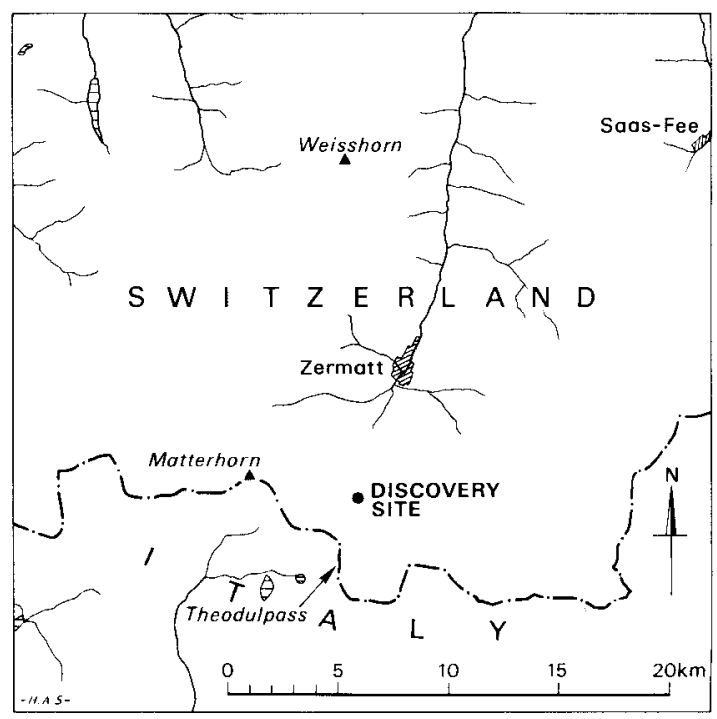

FIGURE 2. Topographic map of the region of Zermatt.

* Peter Lehner, Speerstrasse 39, CH-8805 Richterswil, Switzerland. Annemarie Julen, Chalet Bergkristall, CH-3920 Zermatt. Switzerland. 
roughly $30 \mathrm{~m}$, while the front of the glacier has retreated about $200 \mathrm{~m}$, vis-à-vis the cable car station 'Trockener Steg'. The waning of the Theodulglacier is nothing unusual. The welldocumented retreat of the alpine glaciers in Switzerland began around 1850, marking the end of the 'Little Ice Age' which began at the end of the 16th century.

From the visitors' platform on top of the 'Klein Matterhorn' the glaciated scenery of Theodulpass and the Theodulglacier, with its innumerable crevasses, can be observed from above. It is not difficult to imagine, how weary travellers and merchants laboriously tried to find a way across that icy labyrinth and sometimes didn't make it across.

\section{The discovery}

The first, accidental discovery was of a few coins and a small dagger, during a rest on the moraine of the Theodulglacier after a summertime ski descent.

A first search in autumn 1985 yielded 35 coins, leather from footwear, torn-up pieces of cloth, and a human thigh-bone, some on the ice or just sticking out of the ice, others in the sand of the adjacent moraine. About $100 \mathrm{~m}$ below the site numerous bones and teeth of horses, mules and donkeys lay scattered on the ice, and on the discovery site only a single horse-shoe and some horse teeth were found.

Snow cover prevented further search until September 1986. The glacier had so changed that we found it difficult to identify the site; measurement from fix-points on the moraine showed that the rim of the ice had retreated some $8 \mathrm{~m}$ and a layer of about $2 \mathrm{~m}$ thickness had melted away, bringing to the surface a multi-
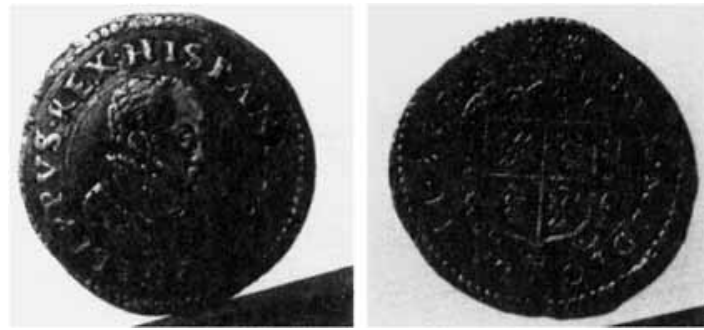

Flgure 3. Silver coin with bust of Philip II, King of Spain (1556-98) on the obverse and the coat of arms of the dukedom of Milan on the reverse. The inscription around the bust of the King 'PHILIPPUS REX HISPANIARUM'. tude of objects. We found about 90 additional coins, amongst them two silver Ducats from the dukedom of Milan (FIGURE 3).

Scanning with a metal detector brought no results, since pebbles of serpentine, a rock which contains magnetite crystals, produced much stronger signals than the coins. A remarkable success was the discovery of a sword with a broken blade and, in 1987, a dagger and a broken pistol were found in the sand of the moraine. A roundish, dark brown object, protruding from the ice like a coconut, was a human skull cap (FIGURE 4).

Less was found during 1988 and 1989, although a similar thickness of ice melted each year - only coins and small pieces of metal or cloth. On our last visit in autumn 1990 we realized that the ice of our 'mother lode' had vanished. Since 1985 the rim of the glacier had retreated some $30 \mathrm{~m}$ and a layer of ice some 5-6

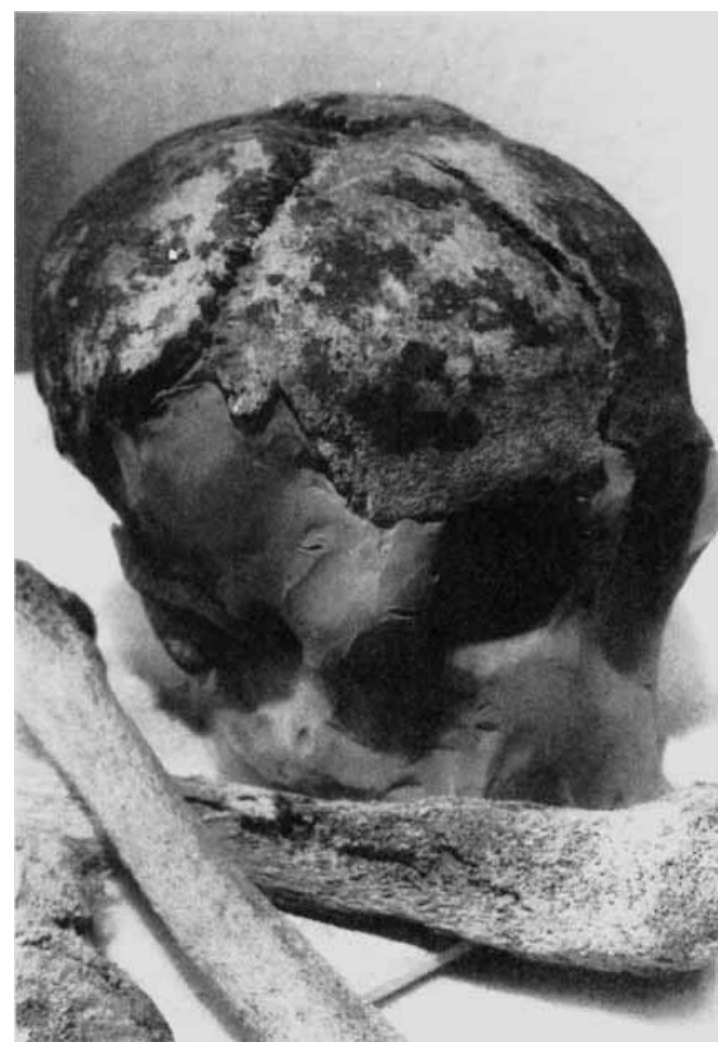

FIGURE 4. Skullcap and bones of the armed man. All bones are completely decalcified and had the consistency of sponge rubber before drying. The carbonate of the skeletal material had dissolved in the ice-water under high pressure. 
$m$ thick had melted, so the skeleton and its belongings lay scattered in an ice mass of at least $5000 \mathrm{cu} . \mathrm{m}$. We assume most of it was washed away and disappeared before we discovered the site.

\section{The finds}

The most remarkable find is the sword (FIGURE 5), $125 \mathrm{~cm}$ long; on the blade is the engraved wolf sign of a German blacksmith, inlaid with copper. This type of weapon was used by mounted soldiers, generally officers, who also carried a pistol instead of a gun (FIGURE 6). The pistol is a typical frontloader with cock and pyrites. The ornaments on the wooden parts are inlaid with fishbone. A wooden vessel with the rest of the metal casing may have served as a container for gunpowder.

The dagger (FIGURE 6), in a remarkable state of preservation, was stuck in a leather sleeve which disintegrated and had to be sacrificed during restoration. As was customary in those days a small knife was attached to the blade. On both sides of the blade are engraved the capital letters C.A.T.O.M.A.

The two silver objects (FIGURE 7) led us to suspect that the bearer enjoyed a certain wealth.
The silver vessel shows a coat of arms with the letters H.N., corrected at a later date to H.A. The bird on the reverse side resembles an Eagle, as it appears on the medieval banner of the city of Brig. The small silver amulet with an engraved cross contains a greenish wax which may have come from a blessed Easter candle.

Shredded pieces of cloth, most not larger than a few square centimetres, were the most common objects. Several large and more or less intact pieces of silk may have come from a shirt. The remaining material consists of very coarse tissue of bluish or reddish tints, some decorated with 'gold braid'.

The individual leather pieces appear to belong to one pair of boots, made of multiple layers of thin leather. The soles show slight signs of wear but were probably fairly new.

\section{The coins}

The coins inform us about the timing of the death on the Theodulglacier and the provenance of the bearer. Of some 200 coins discovered, 9 are large silver pieces and the remainder smaller copper coins. Most were scattered around the skeletal remains on the ice, some washed together by melt-water in small
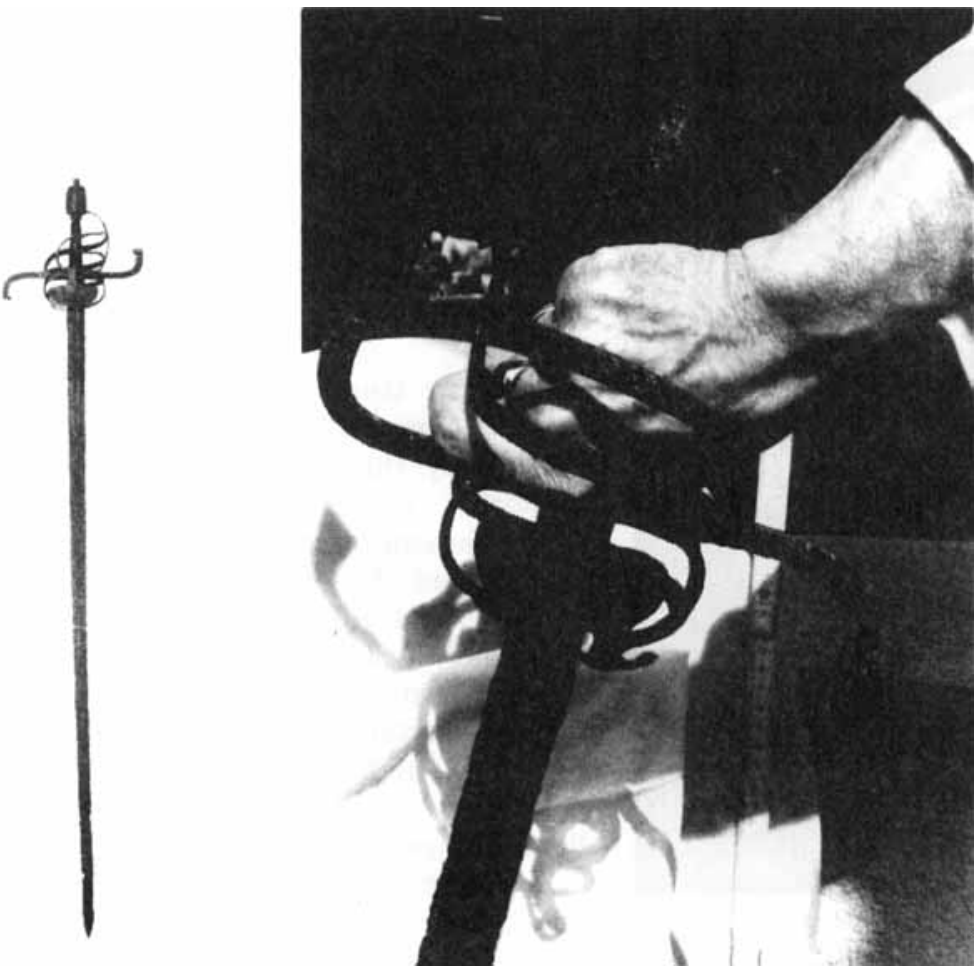

FIGURE 5. A sword 125 cm long, on the blade the 'running wolf' mark of the German swordcutters of Passau or Solingen. 

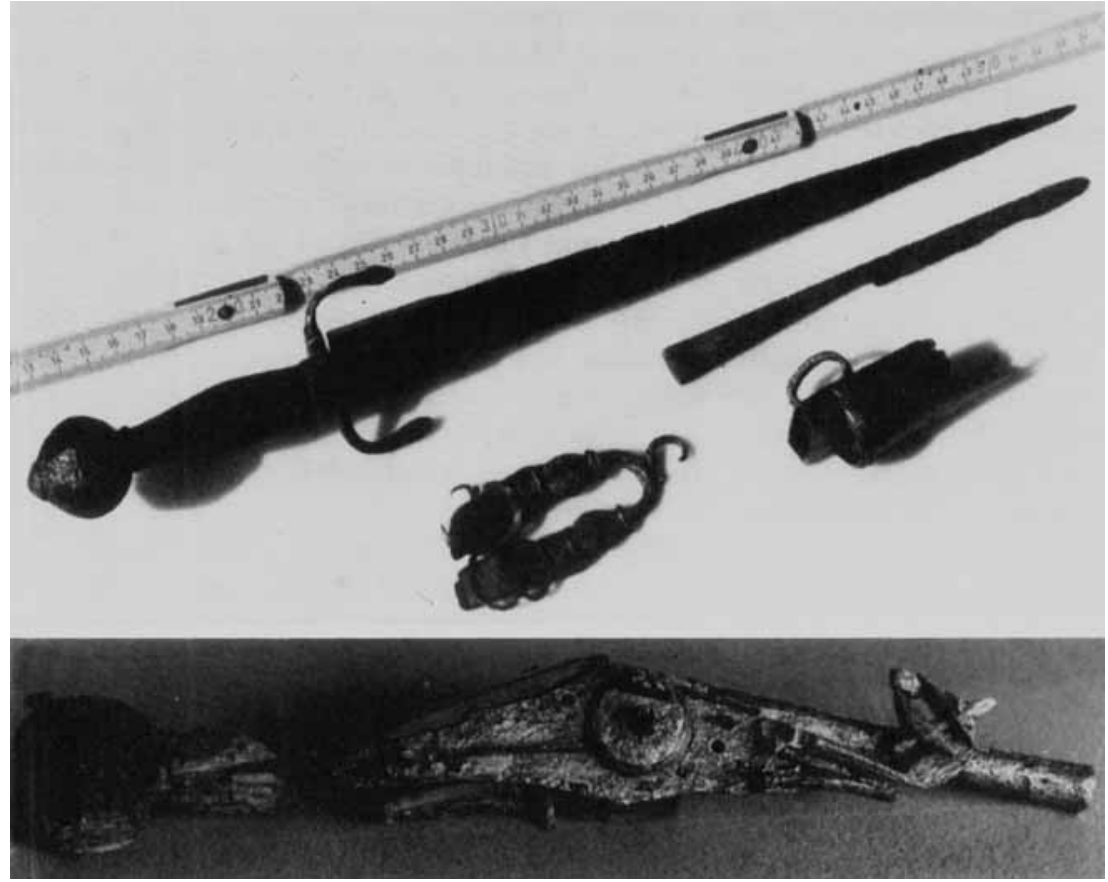

FIGURE 6. Above: dagger $35 \mathrm{~cm}$ long with wooden handle. The leather of the sheath could not be preserved. The small by-knife fitted into the sheath. The inscription on the blade of the dagger reads C.A.T.O.M.A.

Below: the wheellock pistol was found in three separate pieces in the sand of the moraine. It is a typical frontloader with cock and pyrites. The barrel has a length of $18 \mathrm{~cm}$. rivulets on the glacier, others in the sand and gravel of the adjacent moraine. Wherever pieces of garment appeared, coins could be dug out or collected near by. We believe, however, that

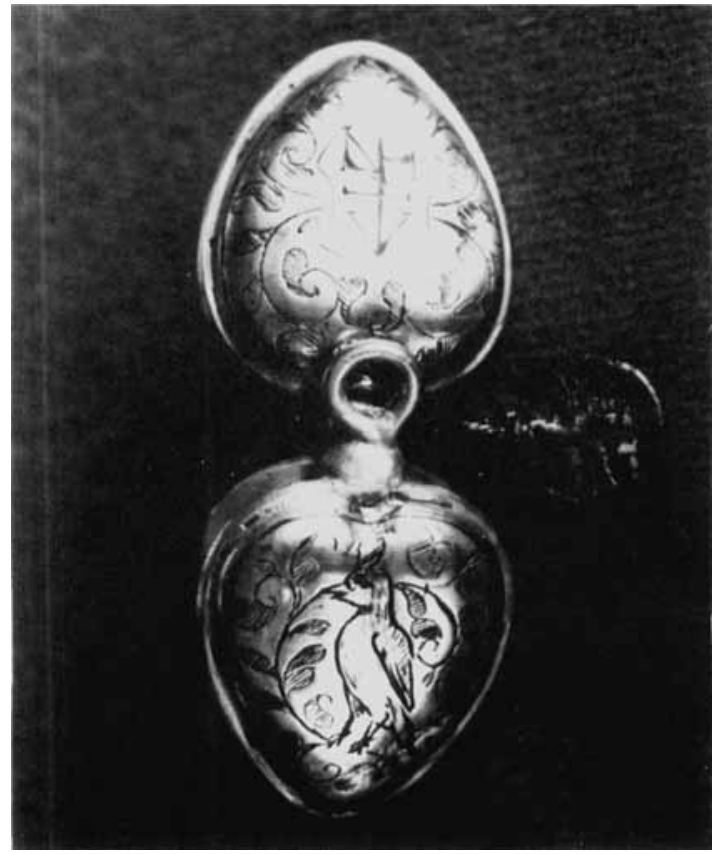

FIGURE 7. Two silver amulets. Diameter across the heart-shaped vessel $3 \mathrm{~cm}$. most of the coins were washed into crevasses and holes in the ice and lost forever. In general the coins are well preserved, with the typical brown patina of copper or the black of silver. Only a few are encrusted with light green malachite or yellow-brown rust.

Six silver pieces depict Philip II, King of Spain and Duke of Milan, three silver pieces Carlo Emmanuele, Duke of Savoy. Forty-five of the coins were minted in Savoy, 17 in Milan, 13 in Mantua and another 25 in smaller dukedoms of upper Italy. Only 7 derive from cities north of the Alps.

Thirteen coins have clearly legible dates, ranging from 1577 to 1588 . The other coins, datable by the reign of the respective mint authority, cover the timespan 1553-1630. Dukes beginning their reign after 1600 are not represented. The fatal event on the Theodulglacier most probably occurred in the last decade of the 16th century.

The pattern of the coinage suggests that the man came from one of the dukedoms in Italy, to the south of the Alps. He may have been a mercenary soldier, in the service of a duke in Piedmont or Lombardy.

In those days Swiss troops were highly thought of by all the powers of Europe. Swiss mercenaries fought for the King of France and 
his vassals, also for his principal enemy Charles $\mathrm{V}$, Emperor of the German Empire and for his son Philip II, King of Spain. The Catholic cantons of Switzerland, for instance, had a special agreement with Philip II to furnish a contingent of 20,000 men. This kind of employment provided an important supplementary income for the Swiss farmers and was though more exciting and rewarding than dull labour on a farm.

\section{The moving glacier ice}

In the Alps above the névé line, in the region of 'eternal snow', the annual snowfall accumulates layer by layer. The fresh powdery snow gradually changes into granular névé and, a. greater depth, into a mass of bluish, transparent ice, which flows downhill under the pull of gravity.

At the position of the discovery site, well below the névé line, the glacier forms a broad ice tongue flowing down at a rate of several metres each year. The ice shows distinct bands, thin layers of clear blue ice alternating with white or greyish opaque layers. Some of the bands contain much mud and sand, and appear dark grey or black. Most of the objects were found near a dark layer.

On the steep walls of a crevasse one can observe that the bands are inclined toward the axis of the glacier tongue with a dip of $35^{\circ}-45^{\circ}$. The glaciologist Prof. Röthlisberger, who inspected the site in 1986, explained that this type of layering is due to the flow of the ice. The laminae are not annual growth layers but sheer horizons in the moving ice mass. This explains the fragmented state of the skeleton, whose broken bones are scattered over a distance of more than $100 \mathrm{~m}$, but it does not explain why we discovered a skeleton rather than a wellpreserved, frozen body of burial. As we think that the body disintegrated before burial within the ice, we believe that the soldier fell into a crevasse, perhaps as a snow-bridge collapsed, in the upper reaches of the glacier near the Theodulpass. Such accidents were quite frequent in the past and usually fatal. A wealthier man might have sent his servant ahead or at least a dispensable animal.

In recent years helicopter transported rigs have been constructed to pull unlucky skiers or mountaineers from crevasses, after freeing them from the deadly grip of the ice with pneumatic hammers. Our soldier was not so lucky. The crevasse closed over his remains, which then began their slow journey down the glacier to emerge after 400 years.

Acknowledgements. We thank Dr M. Senn and his team of the Swiss Museum of Natural History for the restoration of the arms and the silverware. We also thank Dr C. Martin, former president of the Swiss Numismatic Society for helping us with the identification of coins. We also owe thanks to the glaciologist Prof. H. Röthlisberger for the inspection of the discovery site. Special thanks are due to Evi Lehner and Lotti Lehner for their considerable personal involvement in the search and their help with the identification of the coins. We also thank Ronald Perren who discovered the precious silver vessel. We are also grateful to Dr P. Zink of the Swiss Institute of Forensic Medicine for inspecting the skeletal remains.

\section{References}

Corpus Nummorum Italicorum. 1919. Catalogo generale. Rome: Monete medievale e moderne.

Holzhauser, H. 1982. Neuzeitliche Gletscherschwankungen, Geographica Helvetica 37: 115-26.

KRÄMER, M., P. LEHNER \& P. ZINK. 1988. Über zwei Gletscherleichen mit Eisz iten von 70 und 400 Jahren, in Festschrift W. Holczabek, Gerichtsmedizin. Vienna: Franz Denticke Verlag.

Lavanchi, C. 1985. Numismatique valaisanne, Valesia 40. Sion.

LEHNER, P. \& A. JULEN, 1986. Fund mittelalterlicher Münzen, Schuhwerk etc., am oberen Theodulgletscher bei Zermatt, Blätter Walliser Geschichte 19: Sion: 187-200.

1990. Fund eines bewaffneten Mannes aus dem 16. Jahrhundert im Eis des Theodulgletschers, Bull. Schweiz. Petrol. Geol. 56: 71-83.

SANDOZ, J.P. 1986. Die Bastion am Theodulpass. Staefa: Gut Verlag. 